\title{
مفهوم الذات لدى امهات الاطقال زارعى القوقعة
}

$$
\text { إعداد: }
$$

الباحثة/ أميرة محمدي ابراهيم'

\section{إشراف}

د / عزة عبد المنعم رضوان

مدرس بقسم العلوم النفسية

كلية التربية للطفولة المبكرة - جامعة القاهرة
أ. د دهير كامل أحمد

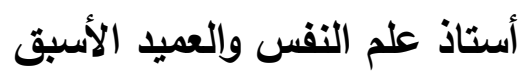

كلية التربية للطفولة المبكرة - جامعة القاهرة

\section{مقدمة :}

يذهب روجرز (Rogers) الى ان الاسرة هى الخليه الاولى فى المجتمع، فهى البيئة النى

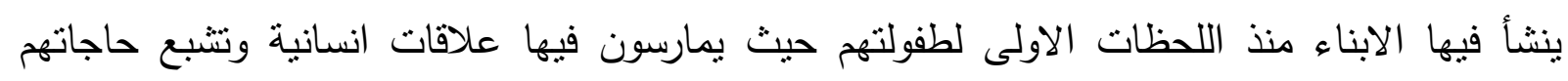

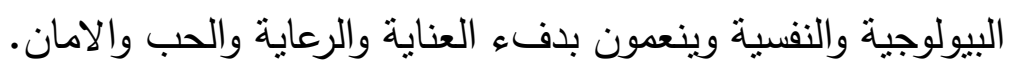

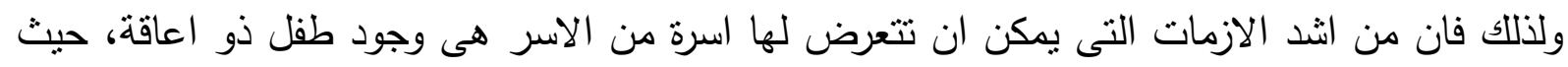

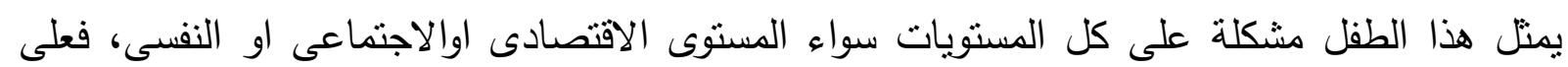

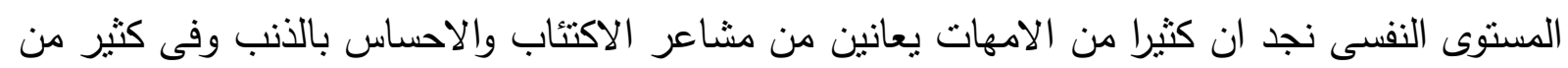
الاحيان ينخفض تقديرهم لذواتهن.

وكثيرا ما تحمل الام على عاتقها مسؤلية العناية بالطفل ذو الاعاقة وتربيتة، وتعتمد فى ذلك على استخدام

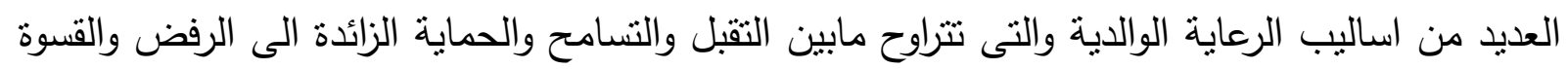

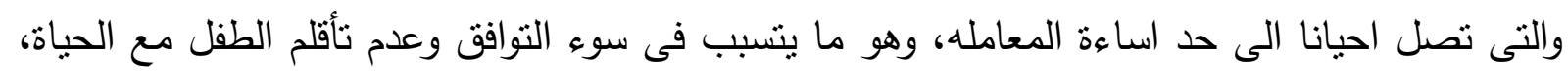
كذلك تعرضة للعديد من الامراض النفسية وخاص عند البلوغ. كما ان اكتثاف الاعاقة السمعية لدى الطفل يسبب الكثير من الضغوط لإط والتحديات النسية لوالدية واسرتة،

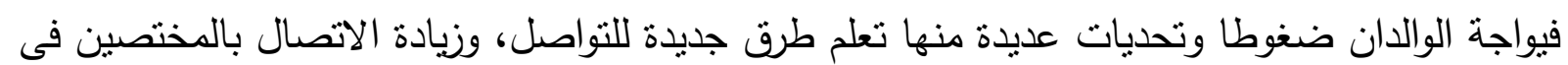

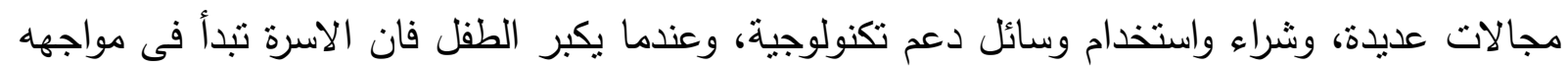

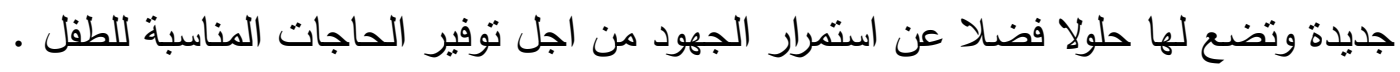


لذللك نستطيع ان نقول ان الاعاقة السمعية للطفل تعد موقفا ضعاغطا للوالدين(وخاصا الام) حيث يؤدى الى تغيير الادوار والتوقعات الاسرية، وقد يطاحب ذلك ردود فعل انفعالية لفقدان الوالدين الامال والطموحات المرتبطة بوجود الطفل. وتظهر هذه الضعوط النفسية والمعاناه لدى امهات الاطفال زارعى القوقعة حتى بعد اجراء عملية الزرع القوقعى لاطفالهن، وذلك نظرا لعده عوامل منها اختلاف استجابة الاطفال لبرامج التاهيل والتدريب ومدى بهى التحسن الذى يطرأ على الطفل، ادراك الام للاعاقة هل تعتبره تحدى واختبار لابد ان تتخطاه ام ستعتبره نوع من سوء الحظ، مساعدة الاسرة وخاصة الزوج، والتاييد والدعم الاجتماعى سواء من الاقارب او الجيران او المهتمين بشؤن الاعاقة، كذلك شخصية الام ومدى قدرتها على التصدى للمشكلات والمرونة فى مواجهه المواقف الصعبة. وعليه فكانت هناك حاجة للتعرف على مفهوم الذات لدى امهات الاطفال زارعى القوقعة وهو ما يهدف اليه البحث الحالى.

مشكلة البحث:

جاءت مشكلة الدراسة من خلا اجراء الباحثة للمقابلات مع امهات الاطفال زارعى القوقعة للتعرف على مهى مدى فعالية جهاز الزع القوقعى على حياه هؤلاء، حيث اثارت معظم الامهات الى المعاناه التى يتعرضون لها جراء اصابة الطفل بالصمم منذ الولادة واجراءات تركيب السماعات و جلسات التخاطب وانتهاء باجراء الزراعة، ولا تتوقف هذه المشكلات والضغوط التى يعانى منها الامهات بمجرد زراعة

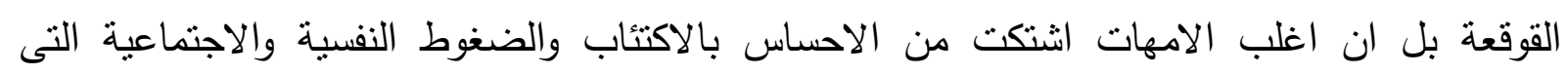
يتعرضون لها سواء من المجتمع ونظرتهم الى اطفالهن او المسؤلية التى تقع على كاهلهن. وعلى هذا يمكن صياغه مشكلة البحث فى الاجابه على السؤال الاتى:

ما هي خصائص مفهوم الذات لدي امهات الأطفال زارعي القوقعة ؟ أهداف البحث:

يهدف البحث الحالي إلى الكثف عن مفهوم الذات لدى امهات الاطفال زارعى القوقعة. اهمية البحث: البحن:

الأهمية النظرية:

ترجع أهمية البحث الحالي إلى أهمية المتغيرات التي يتتاولها البحث وهي مفهوم الذات بتعريفاته وخصائصه والعوامل التي نؤثز في نموه والنظريات المفسرة له، حيث أن فهم الفرد لذاته يمثل مقوماً هاماً من مقومات السواء النفسي، كما ترجع أهمية البحث فى التعرف على مفهوم الذات لدى فئة جديدة وهى (امهات الاطفال زارعى القوقعة) (ملعواء) 


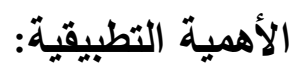

يمكن ان تسهم نتائج البحث فى التعرف على اهم المشكلات والعقبات التى تواجهه اسر الاطفال المعاقين سمعيا وكيفية التظلب عليها، وضع برامج ارشادية لامهات الاطفال زارعى القوقعة بهدف مساعدتهم

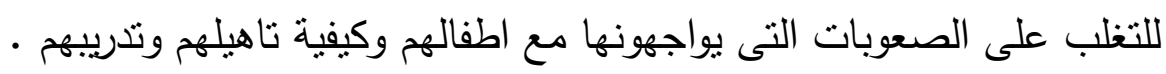

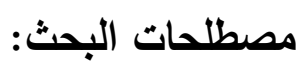

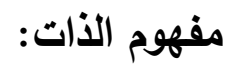

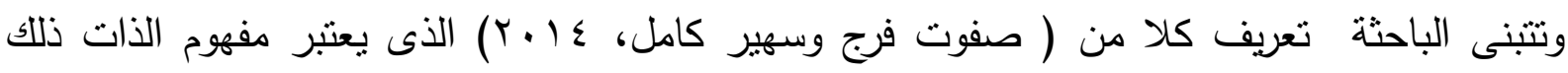

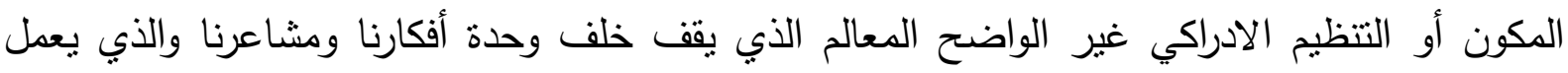
بمثابة الخلفية المباشرة لسلوكنا أو بمثابة الميكانيزم المنظم والموجه والموحد للسلوك، وبهذ الفئا المعنى يلعب مفهوم الذات دور القوة الدافعة للفرد في كل سلوكه"

\section{(صفوت فرج وسهير كامل، ؛ 1 ـ ب: 9 (1).}

\section{الاطفال زلارعى القوقعة:}

أما التعريف الإجرائي للأطفال زارعي القوقعة في البحث الحالى فهم"مجموعة الأطفال الذين يعانون

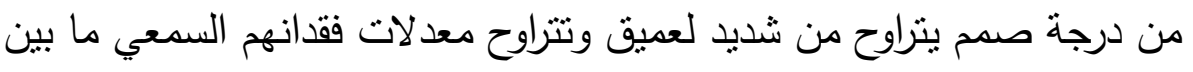

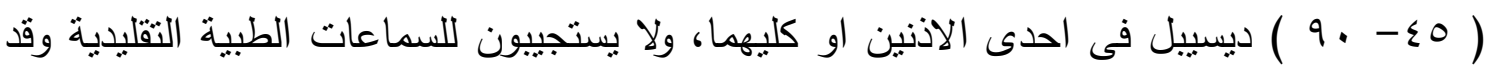

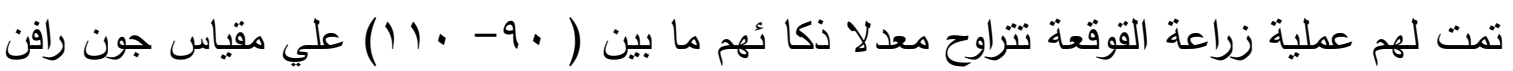

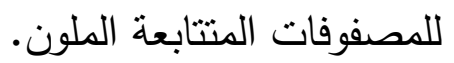

\section{حدود الداسسة :}

يتحدد البحث الحالى بالمتغيرات موضوع الدراسة وهى مفهوم الذات لامهات الاطفال زارعى القوقعة ،

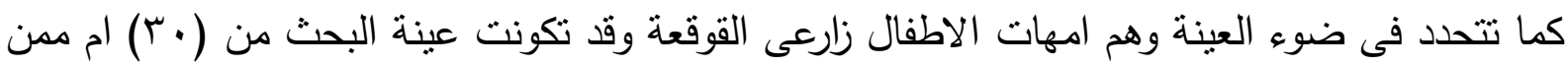
تم اجراء زراعة القوقعة لاطفالهن والذين بعانون من فقدان سمعى شديد الى عميق وتتزاوح اعمارهم من

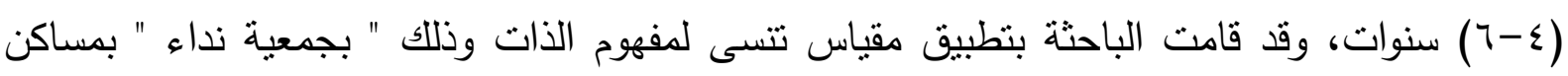

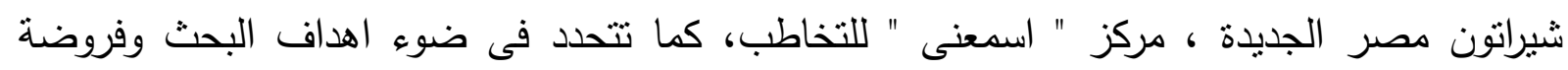
والادوات والاساليب الاحصائية المستخدمة .

ادوات الدراسة : تم الاستعانة بالادوات التالية : ت التانية مقياس تتسى لمفهوم الذات

(اعداد/ صفوت فرج ، سهير كامل احمد : ؛ أ (Y) 


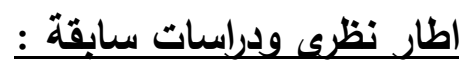

مفهوم الذات :

يعد مفهوم الذات هو الثقييم الخاص والمميز لكل ابعاد الذات ( صورة الذات- نقدير الذات- الذات (Santrock,2001:380)

المثالية)

ويثير مفهوم الذات الى انه ادراك الفرد لمجموعه من الصفات المميزة له، الى انه بمثابة المعرفة العامه بانفسنا، اى ماذا يمكنك ان تعرف او تقول عن نفسك وترتبط هذه المعرفة ارتباطا وثيقا بالخبرات

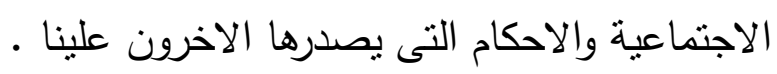

(Buss, 2001:260)(Symington, 2002:418)

هذا ويعرفه (فاروق علوان، ب . . ب) على انه تكوين معرفى منظم وموحد للمدركات الثعورية والتصورات والتعميميات الخاصة بالذات والذى يبلورة الفرد ويعتبره تعريفا لذاته.

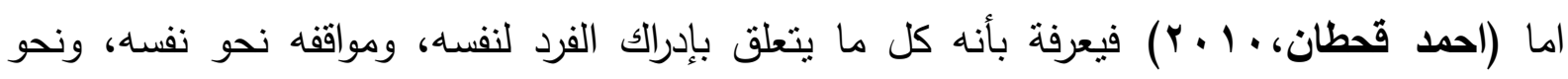

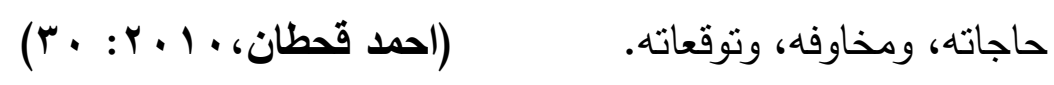

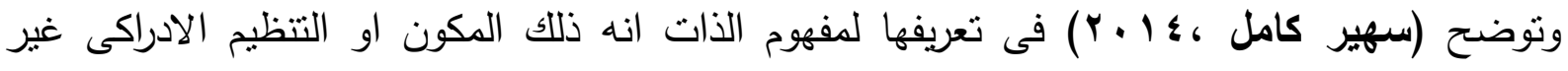
واضح المعالم الذى يقف خلف وحده افكارنا ومشاعرنا، والذى يعمل بمثابة الخلفية المبانشرة لسلوكنا

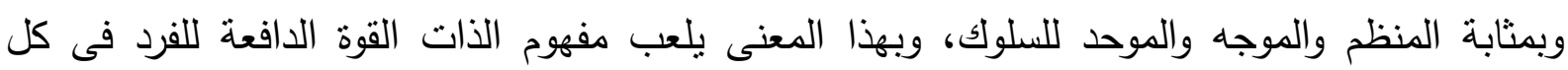

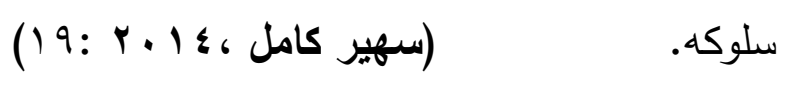

وعلى هذا يمكن القول بان مفهوم الذات هو كيان مركب يتضمن مختلف القرات والخصائص المميزة لثخصية الفرد ومدركاته وتصوراته وانطباعاته ومعارفة وطرق استجابتة وانماطة التوافقية وميوله واتجاهاته داته

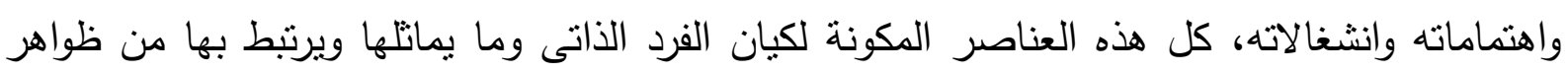
نفسية تتمو وتتبلور من خلال تفاعل خبرات الفرد المتراكبة . وظيفه مفهوم الأت :

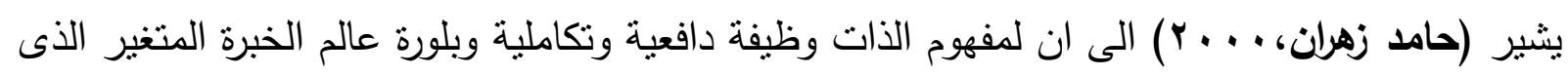

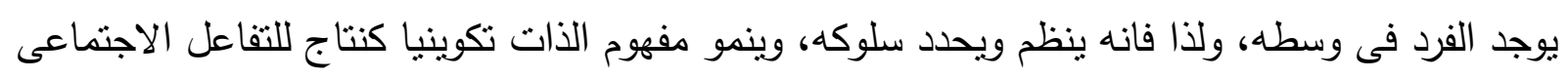

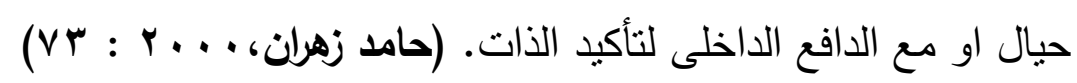

كما ان لمفهوم الذات وظيفة السعى لتكامل الثخصية ليكون الفرد متكيفا مع البيئة الت يعيش فيها،

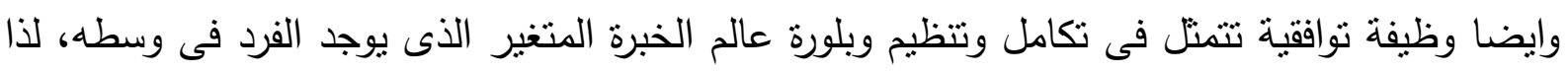

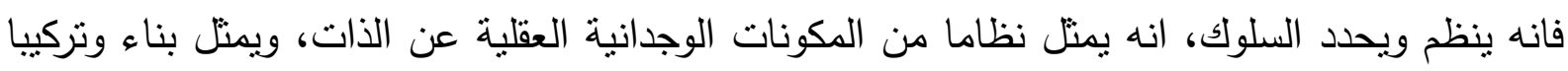

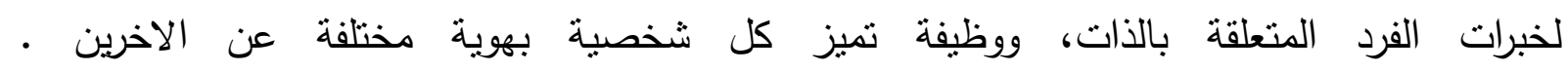

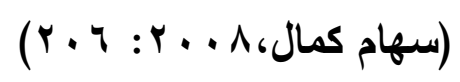




\section{إبعاد مفهوم الأات :}

يرى "كارل روجر" ان ابعاد مفهوم الذات تتضمن : - الذات الواقعية : وهى ادراك الفرد لقدراته ومكانتة وادواره فى العالم الخارجى . - الذات الاجتماعية : وهى الذات كما يعتقد الثخص ان الاخرين يرونها . - الذات الادراكية : وهى عبارة عن تتظيم للاتجاهات الذاتية . - - الذات المثالية : وهى مفهوم الفرد لذاته كما يود ان تكون عليه .

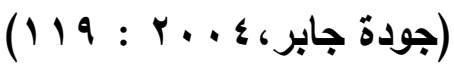

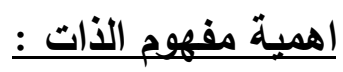

ان اهم مايميز الانسان عن غيره من المخلوقات هى محاولته استخلاص مفهوما خاصا عن ذاته يمثل مصدر الطاقة المحركة لجميع سلوكياتة وذلك من خلال الخبرات الحياتية والمعلومات الخارجية والاحكام التى يصدرها الاخرون، ونجد ان هذا المفهوم عن الذات قد يصبح فى بعض الاحيان اهم من الذات نفسها، ويتضح هذا المعنى اذا نظرنا الى الاشخاص الذين يمرون بخبرات سيئة تجعلهم يقدمون على الانتحار ، فهؤلاء الاشخاص لايستطيعون العيش بمفهوم سىء عن انفسه فيفضلون الموت على الحياه بصورة ذاتية غير جديرة بالاحترام • ولقد ثبت ان مفهوم الفرد عن ذاته يؤثز بشكل كبير فى جوانب سلوكة الختلفة، كما انه متعلق بشكل مباشر بحالته العقليه وشخصيته بوجه عام، ويميل اولئلك الذين يرون انفسهم على انهم غير مرغوبين ولاقيمه لهم او سئين الى السلوك وفق هذه الصورة التى يرون انفسهم عليها، كما يميل اصحاب المفهوم غير الواقعى عن انفسهم الى التعامل مع الحياة والناس باساليب منحرفة وشاذة، وعلى هذا تعد المعلومات الخاصة بكيفية ادراك الفرد لذاته مهمه اذا حاولنا القيام بدور فى مساعدة هذا الفرد ومحاوله الوصول الى ئ تقويمه، وبهذا يلعب مفهوم الذات دورا محوريا فى تشكيل سلوك الفرد وابراز سماته المزاجية، فكل منا ينحو الى ان يسلك بالطريقة التى تتفق مع مفهومه عن ذاته، فمفومنا عن ذاتتا يحكم سلوكنا بشكل

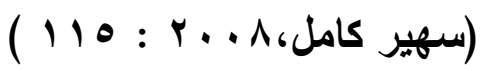
واضح سواء كان هذا المفهوم صحيحا او خاطئًا .

حيث اثنارت نتائج دراسة (Bent,2006) والتى هدفت الى التعرف على الصور الذهنية عن الذات وعلاقتها بمستوى القلق لاى الاباء، حيث اثنارت النتائج الى ان الصور الذهنية عن الذات ترتبط بشكل كبير بمستوى القلق لاى الاباء والامهات، فكلما كانت الصورة الذهنية عن الذات تتسم بالسلبية كلما ارتفع مستوى القلق والذى ينعكس اثره على معاملة الابناء. وكذلك دراسة (شادية محمد مرزوق،و. . . ب) بعنوان مفهوم الذات لدى الام وعلاقته باساءة معاملتها لطفلها المعوق عقليا والاضطرابات السلوكية لديه، وهدفت الى الكثف عن مفهوم الذات لدى ام الطفل ذو الاعاقة العقلية وعلاقتة بالاساءة لهذا الطفل وظهور الاضطرابات السلوكيه لديهم، وتكونت عينة الدراسة

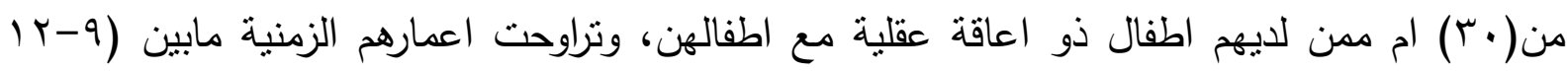


سنه)،وتوصلت نتائج الدراسة الى ان امهات الاطفال ذوى الاعاقة العقلية وذوى مفهوم الذات المنخفض كن اكثر اساءة لاطفالهن، كما ان الامهات ذوى مفهوم الذات المرتفع فى المجموعتين التجريبة والضابطة كن اقل اساءة لاطفالهن. ويرى (Wall,2003) ان مفهوم الذات يرتبط بشكل كبير بثقة الفرد بنفسه وتوقعاته عن ذاته وانجازاته المستقبلية، كما يلعب مفهوم الذات دورا كبيرا فى تأويل الخبرات التى يمر بها الفرد، فالافراد ذوى مفهوم الذات السلبى حينما يفشلون فى عمل ما فانهم يعزون هذا الى اسباب تتعلق بشخصياتهم ، حتى انهم عندما يمرون بخبرات النجاح فان مفهوم الذات السلبى يجعلهم يردون هذا النجاح الى عامل الصدفة بدلا من ان يعزوا هذا النجاح لمجهودهم الثخصى ومهاراتهم الذاتية وقدراتهم الخاصة، وهكذا يظلون فى حاله من الاحباط المستمر الذى يؤثز بلاشك على حياتهم العملية وعلاقاتهم الشخصية وتواققهم بشكل عام .

(Wall,2003: 149)

\section{خصائص مفهوم الأت :}

وقد تم تحديد سبعه خصائص اساسية لمفهوم الذات :

1-مفهوم الأات منظم وتركيبى : ويعنى ان خبرات الفرد المتتوعة تزودة بالمعلومات التى يرتكز عليها فى ادراكه لذاته، ويقوم الفرد باعادة صياغتها وتخزينها بشكل ابسط تسمى التصنيفات وهى

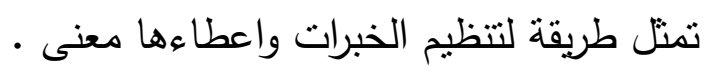
ץ- مفهوم الأات متعدد الجوانب : وهذه الجوانب تعكس نظام التصنيف الذى يتبناه الفرد او بشاركة فيه العديدون واشارت بعض الدراسات الى ان نظام التصنيف هذا يشكل مجالات كالمدرسة والتقبل الاجتماعى والجاذبية الجسمية والقدرة .

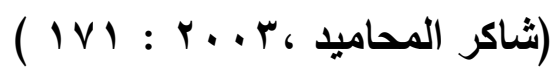

ץ-مفهوم الأات هرمى : اذ يمكن ان تشكل جوانب مفهوم الذات هرما قاعدته خبرات الفرد فى مواقف خاصة، وقمته مفهوم الذات العام وتقمم قمه الهرم الى مكونين هما: مفهوم الذات الاكاديمى الذى يتفرع الى مجالات من المواضيع الرئيسية، ومفهوم الذات غير الاكاديمى والذى ملى يتفرع الى مفهوم اجتماعى ومفهوم عاطفى . ع - مفهوم الأات ثابت نسبيا : اي انه يتسم بالثبات النسبى وكلما كان الاتجاه فى مفهوم الذات نحوم

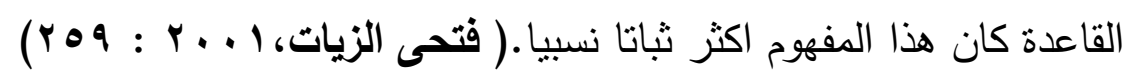
ه- مفهوم الذات نمائح ومتطور: فالاطفال لايميزون فى بداية حياتهم انفسهم عن البيئة المحيطة، وهم غير قادرين على التسيق بين الاجزاء الفرعية للخبرات التى يمرون بها، وكلما نما الطفل تزداد خبراته ومفاهيمية ويصبح قادرا على ايجاد التكامل فيما بين الاجزاء الفرعية لتشكل اطارا

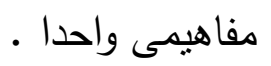


צ- مفهوم الأات فارقى: بمعنى انه متمايزا او مستقلا عن الابنية الاخرى النى تربطه بها علاقة

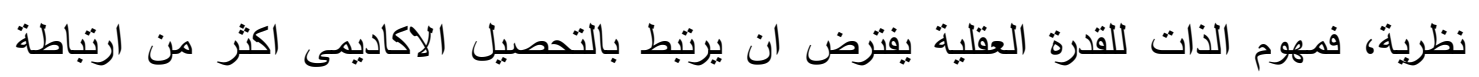

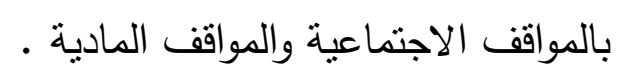
V- مفهوم الذات تقويمى : مفهوم الذات ذو طبيعة تقييميه، وهذا لايعنى فقط ان الفرد يطور وصفه

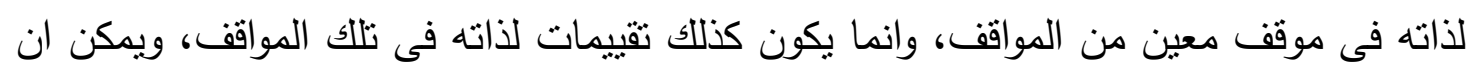
تصدر تلك النقييمات بالاشارة الى معايير مطلقة كالمقارنة المثالية، او يمكنه ان يعدد تقيماته

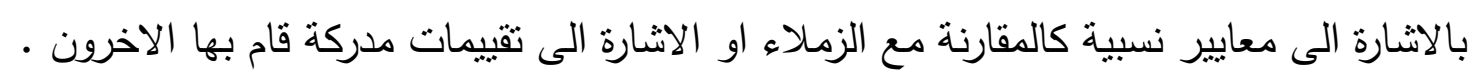

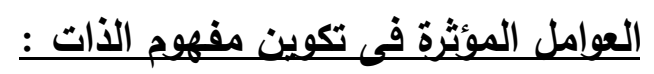

عوامل ذاتيه : تتمنل فى الخصائص الجسمية (صورة الجسم)، والقدرة العقلية كالذكاء.

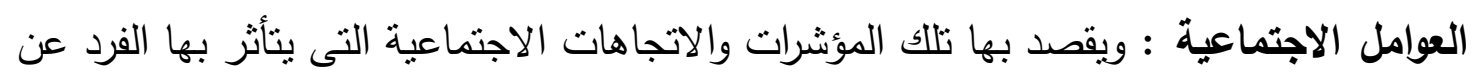

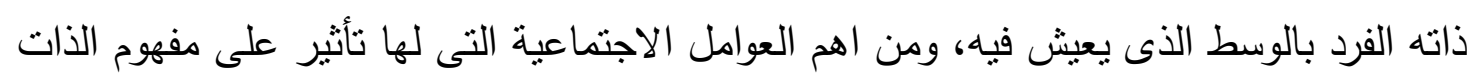

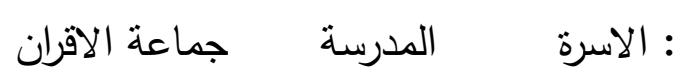

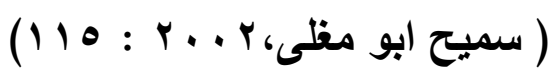

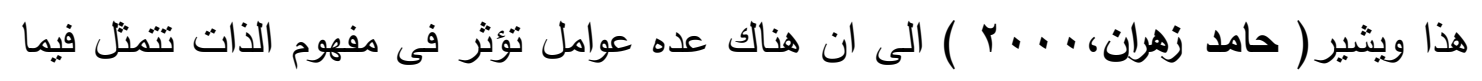
يلى : لئى - الثأثيرات الجسمية ويقصد بذللك اثر صورة الجسم فى بناء مفاهيم معينة عن الذات، فالعيوب والعاهات تتمى مشاعر النقص احيانا . - مترتيب ولادة الطفل فى الاسرة

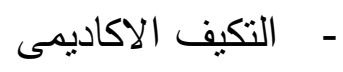

- العوامل والظروف الاقتصادية الافضل تساعد على تتمية مفاهيم اكثر ايجابية

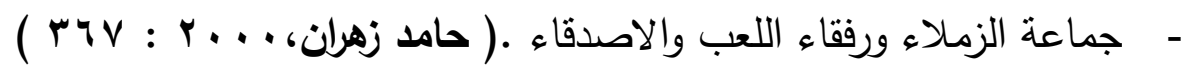

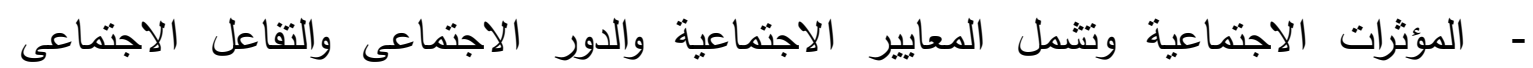
والمميزات الاسرية. حيث تلعب المعايير الاجتماعية دورا هاما بالنسبة لدفهوم الذات، فقد بينت الدراسات ان العوامل

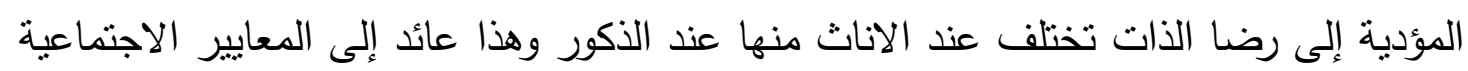

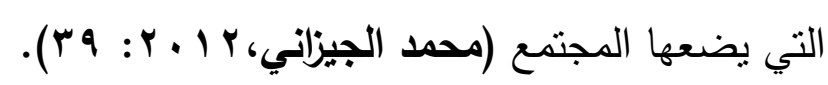

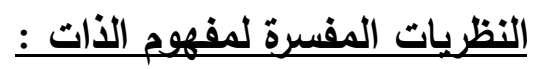
هناك العديد من النظريات الخاصة بمفهوم الذات وسوف تقوم الباحثة بعرض لاهم النظريات : 
النظرية الادراكية :

يثير Yamomoto(1972 ) الى ان مركب الذات هو ذللك التنظيم الادراكى الانفعالى الذى يتضمن

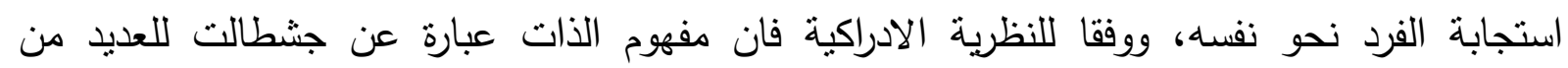

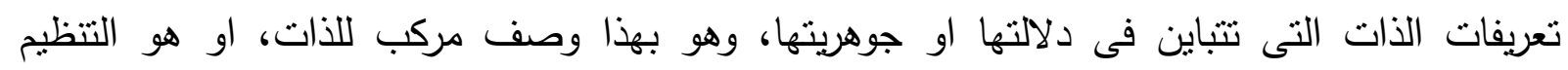
الادراكى الانفعالى الذى يتضمن استجابات الفرد نحو نفسه ككل.

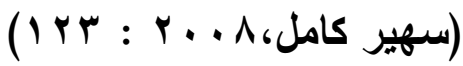

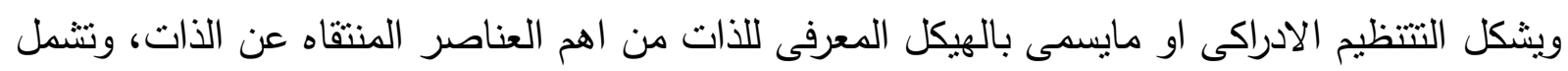

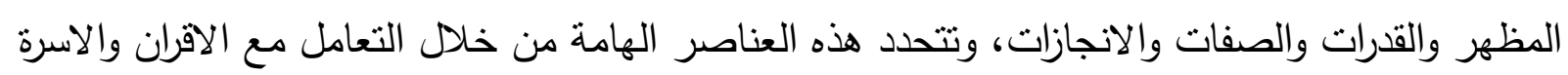

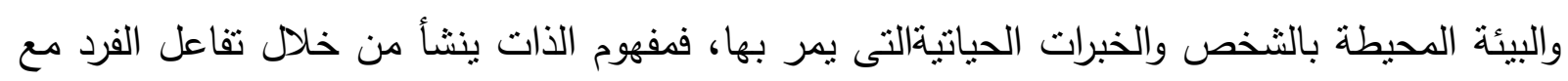

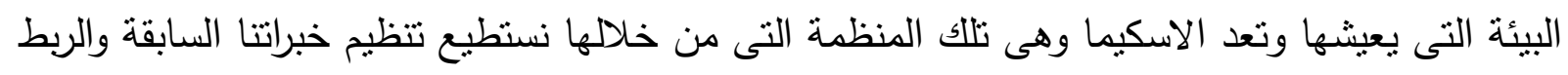

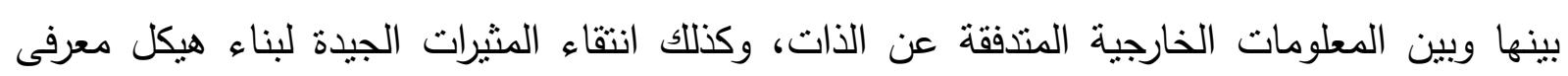
بمثاية المفهوم الاساسى المقوم للذات.

(Buss, 2001:559) (Hippel \& Hamkins, 2001:1213)

(Bauman \& Kuhl,2002:193) (Franzoi,2003:60)

ويرى ادلر Adler ان تحقيق الذات دافع فطرى وجزء من الحياة، بل انه الحياة ذاتها، وان مشاعر

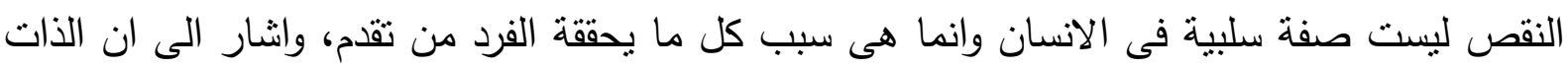

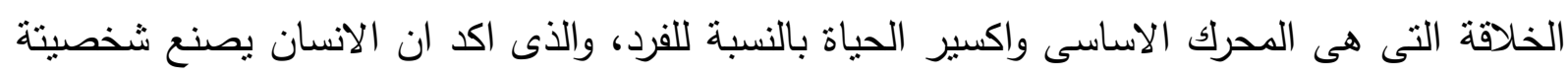

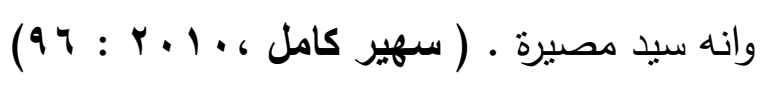

نظرية الذات لكارل روحن

يعرف روجرزRogers مفهوم الذات بانه نمط تصورى منظم ومرن يتكون نتيجة لتفاعل الفرد

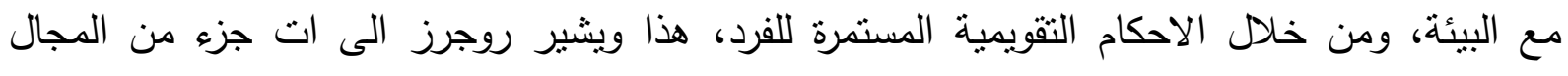

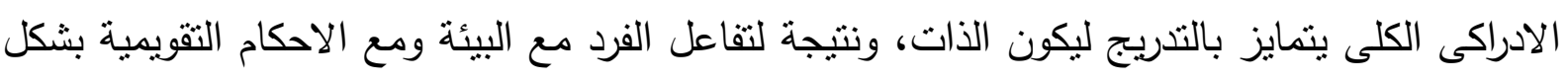
خاص يتكون مفهوم الذات، فالطفل يميز ذاته كثىء بارز عن باتهن الطبيعة التى يعيش فيها، وحين يتعلم

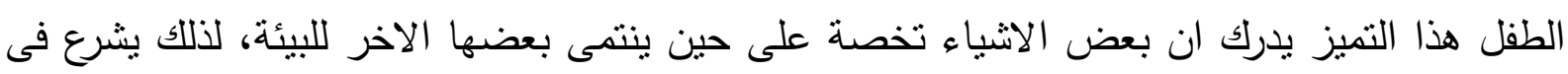

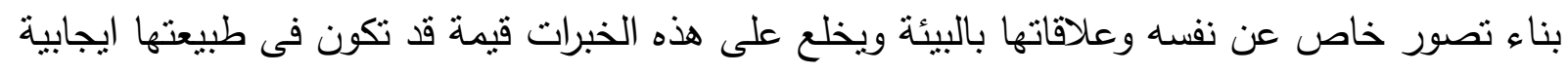
او سلبية، وعندها بصبح بناء الذات صورة منظمة قائمة فى الوعى كثكل (شعور ) او كارضية (لاشعور )

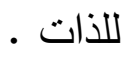

كما يشير روجرز الى الدور الهام جدا والمؤثر لمفهوم الذات فى نجاح عملية التوافق المطلوبة مع العالم

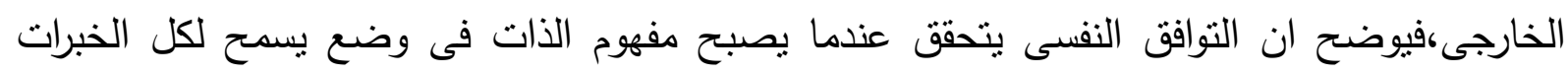


الحسية او الحشوية للفرد بأن نصبح متمنلة فى مستوى وعلى علاقة ثابتة ومنسقة مع مفهوم الذات.

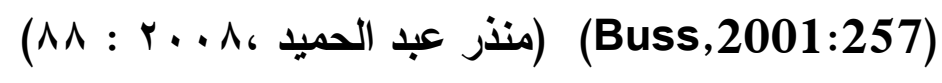

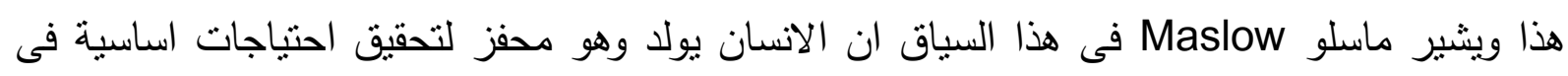

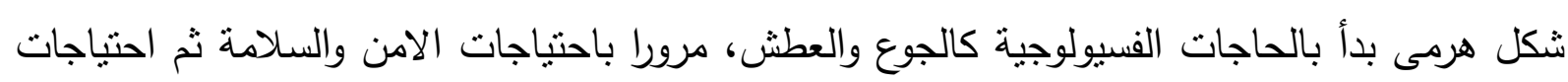

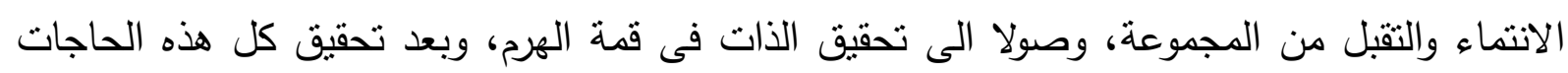

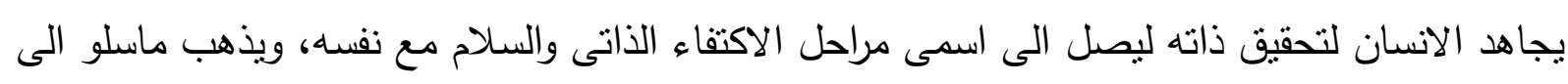

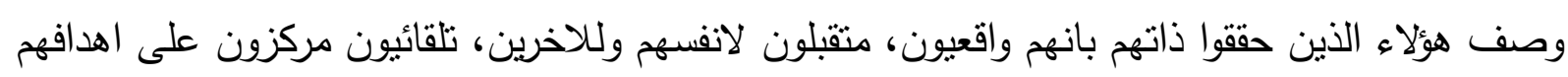

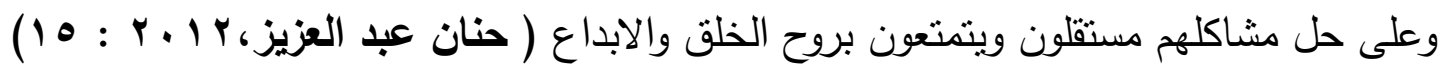

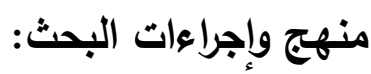

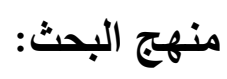

استخدم البحث الحالى المنهج الوصفى ، ولقد اتبعت الباحثة اجراءات المنهج الوصفى والذى يستخدم

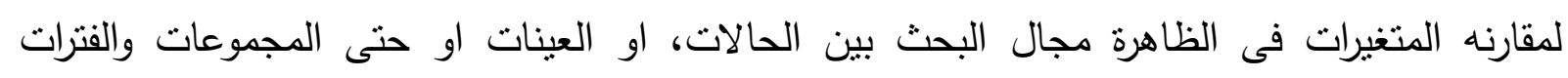

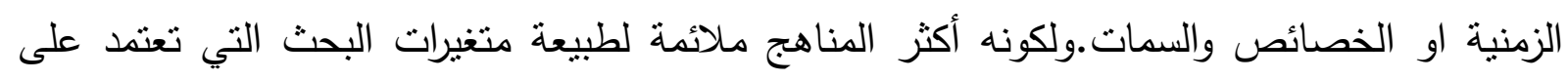
الوصف والتحليل. عينة البحث: - مئ طبق مقياس (مفهوم الذات) على عينة من امهات الاطفال زارعى القوقعة الالكترونية وتكونت عينة

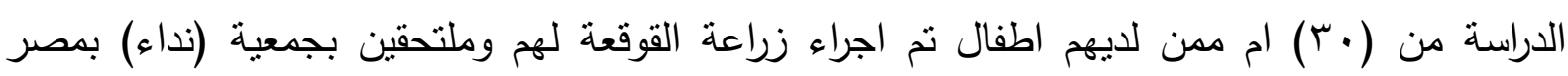

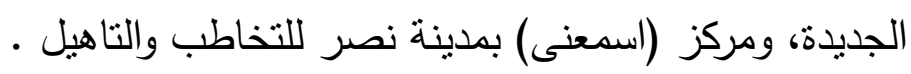
أدوات البحث: استخدمت الباحثة فى البحث الحالى مقياس تتسي لـفهوم الذات

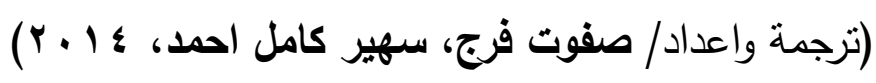

وفيما يلى وصف للاداة:

Self concept استخدم مقياس تتسى لمفهوم الذات، وهو مقياس متعدد الابعاد فى وصفه لمفهوم الذات وصفات

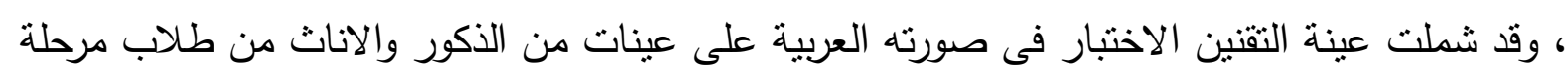

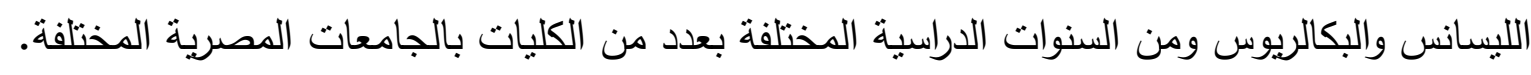

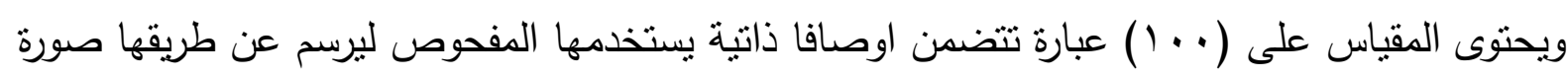
ذاتية عن شخصيتة، ويطبق المقياس بواسطة المفحوص سواء اكان فردا ام جماعة، ويمكن استخدام

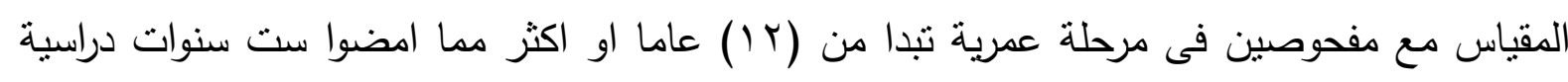

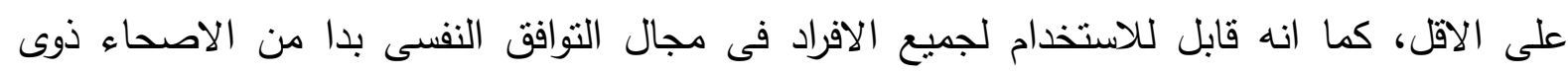
التوافق الجيد وحتى المرضى الذهانيين. 
واستخدت الباحثة فى البحث الحالى المقاييس التجريبية من المقياس وفيما يلى وصفا لها :

1- مقياس الدفاعات الموجبة (دج)

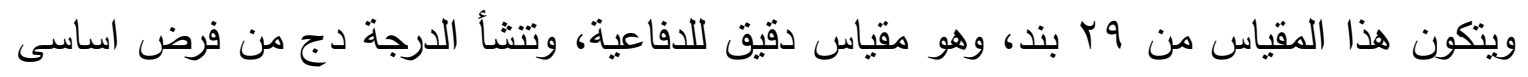

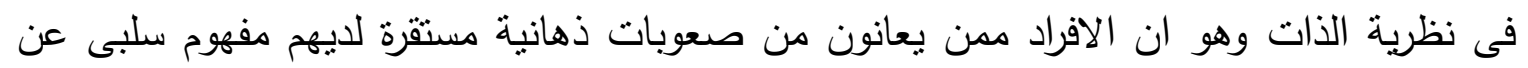

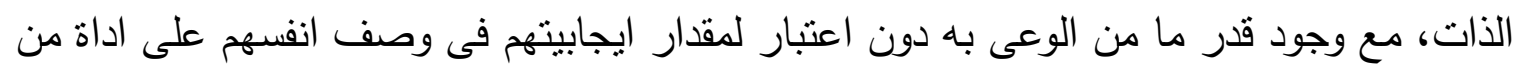

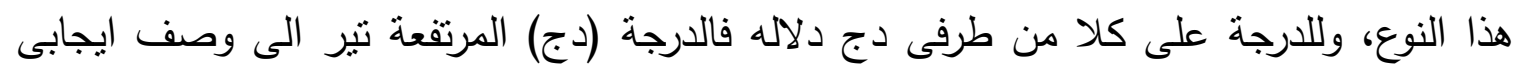

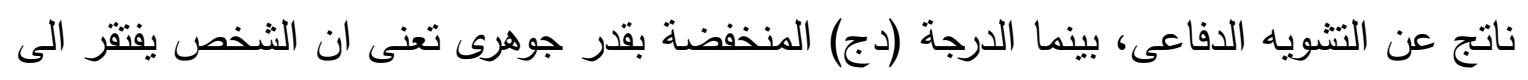

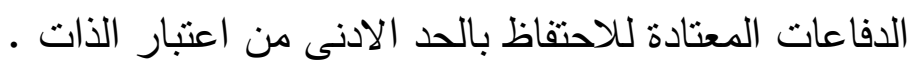
r - مقياس سوء التوافق العام (س ت) ويتكون هذا المقياس من (ع ب) بندا تميز المرضى السيكاتريين من غير المرضى، ولكنها لا تميز

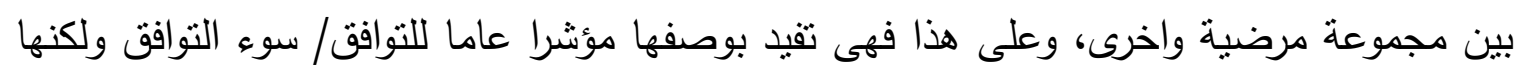

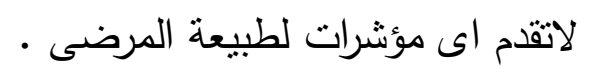

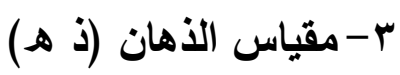

يتكون مقياس (ذ هـ ) من بr بندا هى التى توفر افضل تمييز للذهانتين من بين بقيه المجموعات.

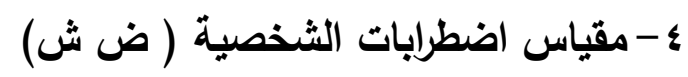

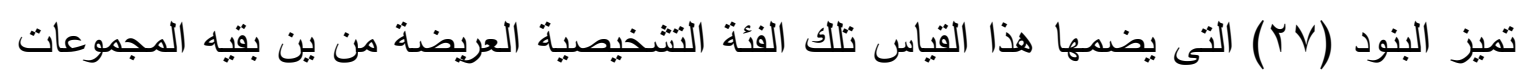

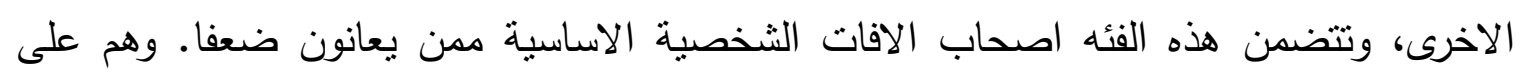

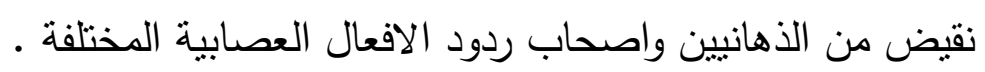

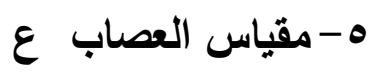
ويتكون من (rV) بندا وتعنى الدرجة المرتفعة ان صاحبها ينتابه الى حد كبير مع المجموعة من

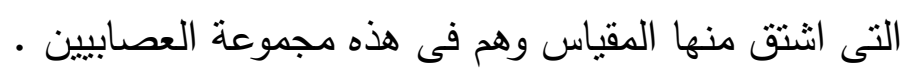
1- مقياس الثخصية (ت ش)

ويتكون من (ro) بندا تميز مجموعة اصحاب الثخصية المتكاملة عن بقية المجموعات (يطبق الثبات المقياس تطبيقا ذاتيا بواسطة المفحوص نفسه ) وتم حساب الثبات باستخدام طريقة القسمة النصفية زوجى -فردى لكل مقياس من المقاييس التجريبيية على حده ، وكانت معدلات الارتباط مرتفعة من العينة المصرية.

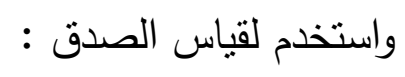
- - مدق التكوين - - الارتباط بيطاريه مينسوتا متعددة الاوجة للشخصية - - الارتباط بيطارية ايزنك للشخصية ل 
- - الارتباط بمقياس تيلور للقلق

خطوات إجراء البحث:

- تحديد عينة البحث من جمعية نداء ومركز اسمعنى للتخاطب والتاهيل .

- تطبيق مقياس تتسي لمفهوم الذات.

- تحليل النتائج باستخدام الأساليب الإحصائية المناسبة.

عرض التتائج:

تجانس العنية من حيث العمر الزمنى

قامــت الباحثتة بايجـاد التجـانس بـين متوسـطات رتـب درجـات امهـات الاطفــال زارعـى القوقعـة مـن

حيث العمر الزمنى باستخدام اختبار كا`` كما يتضح فى جدول (1)

جدول (1) (1)

دلالة الفروق بين متوسطات رتب درجات امهات الاطفال زارعى القوقعة

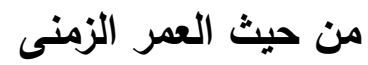

$r \cdot=\dot{0}$

\begin{tabular}{|c|c|c|c|c|}
\hline مستوى الدلالة & كاץ & الانحراف & المتوسط & المتغيرات \\
\hline غير دالة & $r$ & $r, \leqslant Y$ & $r r, \leqslant 0$ & العمر الزمنى \\
\hline
\end{tabular}

عند درجة حرية9

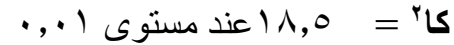

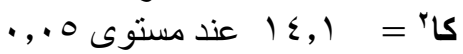

يتضــح مسن جـدول (1) عـدم وجـود فـروق دالـة احصــائيا بـين متوسـطات رتـب درجـات امهـات الاطفال زارعى القوقعة من حيث العمر الزمنى مما يشير الى تجانس أفراد العينة. نتائج تساؤل البحث : وكان تساؤل البحث كالتالى

ما هي خصائص مفهوم الذات لدي امهات الأطفال زارعي القوقعة وللتعـرف على مفهـوم الـذات لـدى امهـات الاطفـال زارعـى القوقعـة سـتقوم الباحثـة بعـرض نتـائج البحث الحالى ومقارنتها بعينة التقنين 
جدول (r)

مفهوم الذات لاى امهات الاطفال زارعى القوقعة على مقياس مفهوم الذات

\begin{tabular}{|c|c|c|c|c|}
\hline \multicolumn{2}{|c|}{ نتائج عينة التقتين } & \multicolumn{2}{|c|}{ نتائج عينة البحث } & \multirow[b]{2}{*}{ المقياس } \\
\hline$\varepsilon$ & p & $\varepsilon$ & s & \\
\hline 12.08 & 55.14 & 10.27 & 50.95 & الدفاعات الموجبة \\
\hline 9.90 & 83.53 & 9.7 & 64.1 & سوء التوافق العام \\
\hline 6.92 & 58.14 & 12.49 & 60.45 & 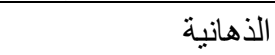 \\
\hline 12.16 & 70.86 & 18.43 & 76.4 & اضطر ابات الثخصية \\
\hline 11.74 & 75.54 & 14.61 & 62.3 & العصابية ل مابية \\
\hline 6.93 & 5.74 & 1.98 & 3.95 & تكامل الثخصبة \\
\hline
\end{tabular}

من الملاحظ فى جدول رقم (Y) انه لاتوجد فروق بين اغلب المتوسطات والانحرافات المعيارية التي خرج بها البحث الحالي وتلك التي خرجت بها عينة التقنينن وذلك في اغلب المتغيرات وان كانت

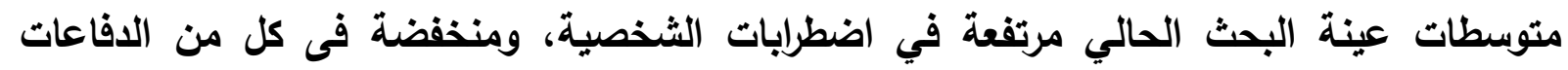

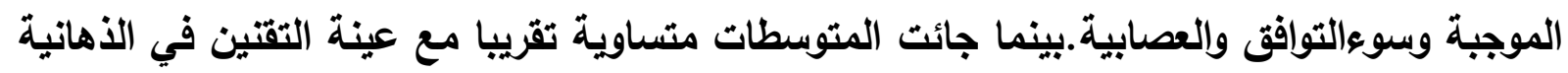
وتكامل الثخصية.الا ان الانحرافات المعيارية ارتفعت كثيرا علي بعد الذهانية وإظطرابات الثخصية

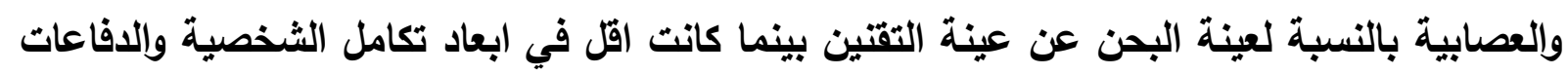

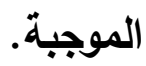
في الضوء النتائج بجدول رقم (ץ) يمكن وصف خصائص مفهوم الذات لاى امهات الاطفال زارعى القوقعة كالتالى : القئ - أشارت نتائج الامهات على مقياس الدفاعات الموجبة الي ان المفحوصات لديهن فكرة موجبة عن ذواتهن وتعبر درجاتهن عن وصف إيجابي للذات ناتج عن احتفاظهن بقدر مرتفع من اعتبار الذات، وانه من الصعب بالنسبة لهن قبول مفهوم ذات سلبي عن ذواتهن، كما يمكن وصفئ عنهن

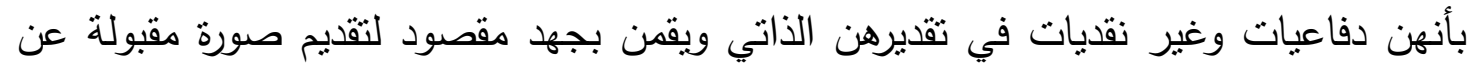

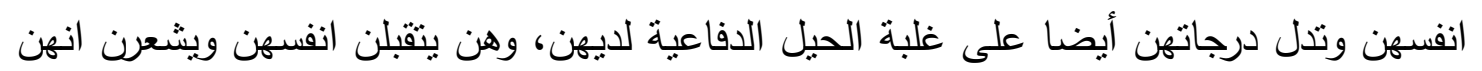
انخخاص من ذوات القيمة ينقن في انفسهن ويتصرفن وفقا لذلك.

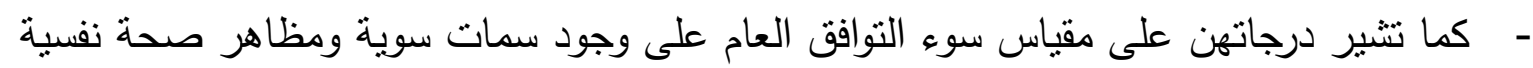
وخلوهن من الاعراض غير السوية وهذا يتفق مع نتائجهن على البعد السابق وهو بعد الدفاعات الموجبة، ويكثف عن وصف موجب للذات على الرغم من انه بتضمن نتويها دفاعيا الا انه يرتبط بسمات السواء فاللاتي يشعرن بانهن اشخاص من ذوات القيمة لا يشعرن بالقلق والاكتئاب وعدم السعادة بل على العكس بشعرن بالتوافق والثشعور بالسعادة وبانهن مستقرات في بيئتهن. 
- كما نلاحظ خلو الأمهات المفحوصات من أي صعوبات ذهانية مستقرة وهذا يتفق مع درجاتهن على مقياسي سوء التوافق العام والدفاعات الموجبة فكانت درجاتهن على مقياس دفاعات موجبة ليست منطرفة ارتفاعا او انخفاضا والتي عادة ما يحصل عليها مرضى الذهان بوجه عام، اما في بعد اضطرابات الشخصية فدرجات المفحوصات نثابه درجات تنامل الثخصية في دراسة (فيتس)، أي أن درجاتهن جيدة وفي الإطار السوي وهذا ما ظهر أيضا على بعد العصابية في مقياس العصابية. - وعلى ضوء هذه النتيجة نستطيع القول بأن مفهوم الذات ينشأ من خلال تفاعل الفرد مع البيئة التي يعيش فيها، كما أن النتائج التي توصلنا إليها تشير إلى دور عوامل التششئة الاجتماعية على مفهوم الذات لدى أمهات الاطفال زارعي القوقعة،ونشير أبضا إلى وجود سمات شخصية مشتركة بين المفحوصات مما أدى إلى التقارب بين مفاهيم الذات لديهن. - ان الإيجابية في وصف الذات تشير بقدر من الوضوح إلى الخلو من الاضطرابات الثخصية وان الدفاعات الموجبة (مكانيزم توافقي) يستخدمه الفرد في حدوده المتوسطة في مواجهة مشكلاته المختلف ة وهناك قدر لا بأس به من الدلائل يشير إلى أن مفهوم الأشخاص عن ذواتهم يتغير نتيجة للخبرات والتجارب العميقة التي يمرون بها.

ومما يؤكد النتائج السابقة نتائج الدراسة التى قام بها (Nader Saki. et.al, 2017) بعنوان اثز زراعة Investigating the القوقعة على السعادة وتقدير الذات لدى امهات الاطفال ذوى الفقد السمعى الثديد impacts of cochlear implantation on the Happiness and self Esteem of mother of children with severe hearing loss والتى هدفت الى مقارنة السعادة واحترام الذات لاى امهات الفقد السمعى الثديد قبل وبعد اجراء زراعة القوقعة، حيث يعانى الاطفال ذوى الفقد السمعى الثديد من اجل التواصل مما ينعكس على الحالة النفسية للام بالاضافة الى كيفية تقديم الرعاية والتواصل معهم وذلك بسبب هذا الحاجز، حيث ان تحسن الادراك السمعى للاطفال يساعدهم على التواصل الجيد وبالتالى تحقيق السعادة النفسية بين الاطفال وامهاتهم فى ، وتكونت عينة الدراسة من (• ع) ام من الاطفال ذوى الفقد السمعى الثديد، وتوصلت نتائج الدراسة الى وجود فروق كبيرة بين درجات السعادة واحترام الذات لدى الامهات بعد اجراء زراعة القوقعة، كما اشارت الدراسة الى ان اجراء عملية الزرع القوقعى يؤدى الى تحسين مستوى السمع لدى الاطفال مما يعود بالفائدة على الاسرة وبالتالى تحسين التواصل مع اطفالهن.

Stigma in mother of Deaf بعنوان بتفق هذا مع دراسة (Hossein Ebrahimi. et al,2015) children 
حيث يخلق الطفل الاصم شعورا بالوصم لدى العديد من الاباء السامعين، ويؤثر هذا الشعور لدى الامهات تأثيرا سلبيا وبشكل مباشر على معاملة الطفل واعادة تأهيله، وقد اجريت هذه الدراسة المستعرضة على (·9) ام لاطفال مصابين بالصمم وتم تطبيق مقياس الوصم لدى الامهات الاطفال الصم، وتوصلت النتائج الى ان معظم الامهات يعانين من الثعور بالوصم والخزى لوجود طفل اصم بالاسرة، كما تعانى الامهات من الثعور بنظرات السخرية والاستغراب والخجل، بينما انخفض معدل بعل بهن الثعور بالخرى والوصم فى امهات الاطفال زارعى القوقعة . وترى الباحثة ان مفهوم الذات الايجابى يؤدى الى نوع من الاتزان الداخلى الذى يتبلور فى وجود شخصية

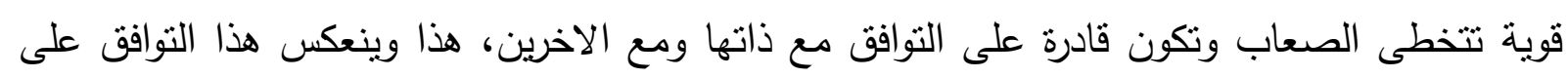
قدرة الام فى اقامة علاقات حميمة مع افراد اسرتها وخاصة الزوج الذى يعد الداعم الاول للام فى محنة الاعاقة، كما نجد ان الام تكون قادرة على اقامة علاقة جيدة بالاخرين الذين يدعمون الام بشكل كبير مما يساعدها على التخفيف من اعباء الاعاقة والتغلب على ظروفها الصعبة وهذا ما اشثار الية كلا من (

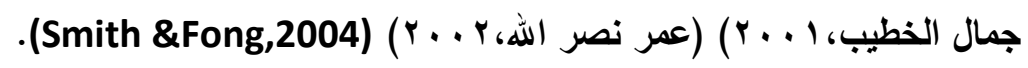

ويوضح الثكل رقم (1) متوسطات ابعاد مفهوم الذات علي عينة البحث وعينة التقنين

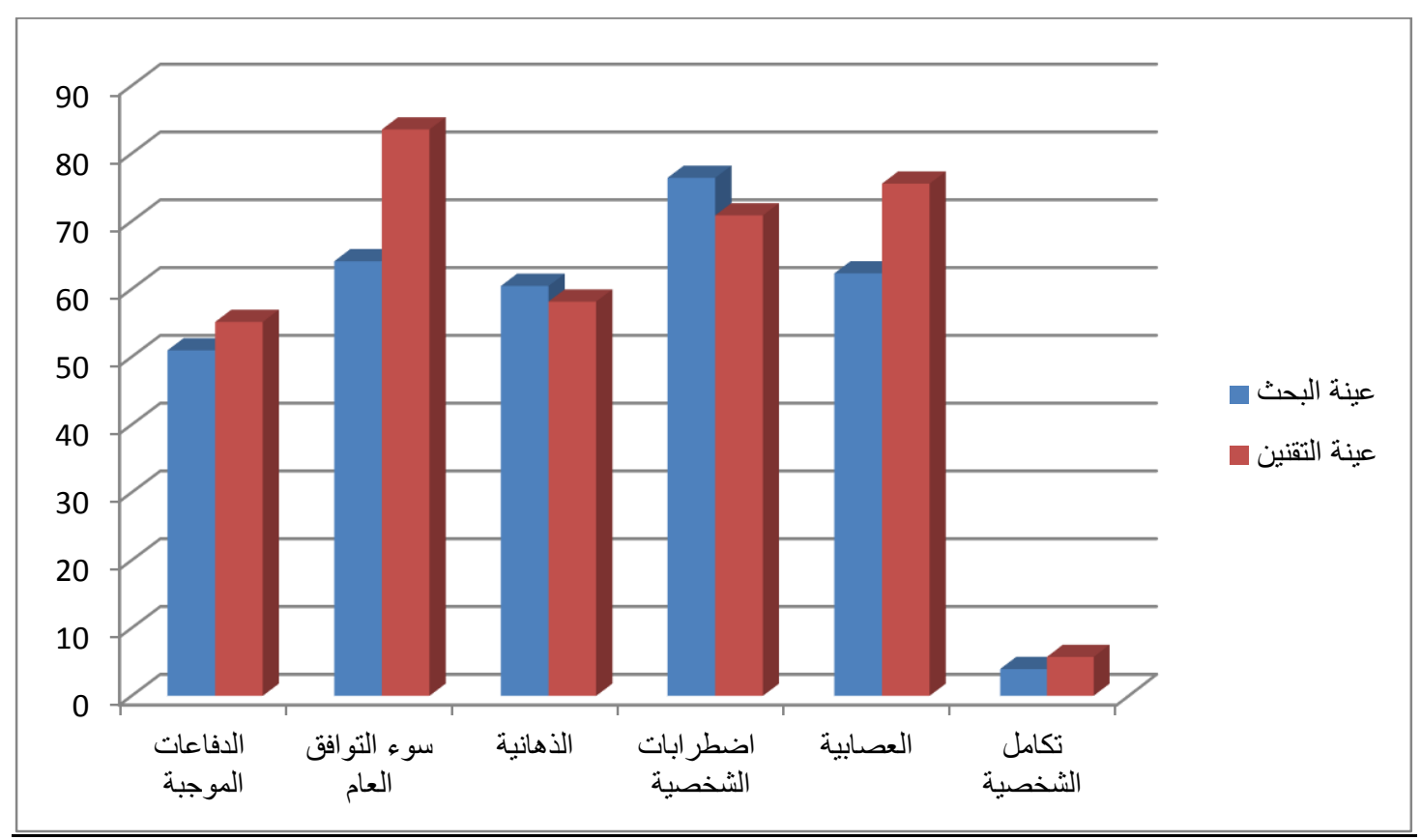

متوسطات ابعاد مفهوم الذات علي عينة البحث وعينة التقنين

توصياث البحث :

عمل برامج ارشادية وتوعية لامهات الاطفال زارعى القوقعة . تتظيم جلسات ارشارد جماعى لتبادل الخبرات بين الامهات. 


\section{البحوث المقترحة :}

فى ضوء نتائج البحث الحالى تقترح الباحثة اجراء البحوث التالية

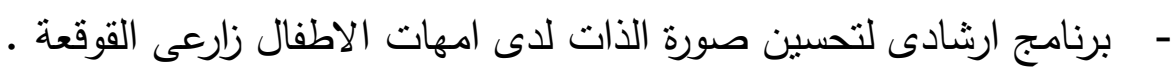
- - الصفحة النفسية لامهات الاطفال زارعى القوقعة . - برنامج ارشادى لتتمية مهارات اباء وامهات الاطفال زارعى القوقعة ومساعدتهم فى رعاية ل

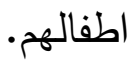

\section{: المرلجيع}

1-جمال الخطيب( ( + . ). اولياء امور الاطفال المعوقين واستراتيجيات العمل معهر وتدريبهح ودعمهر. سلسلة اصدارات اكاديمية التربية الخاصة .الرياض.

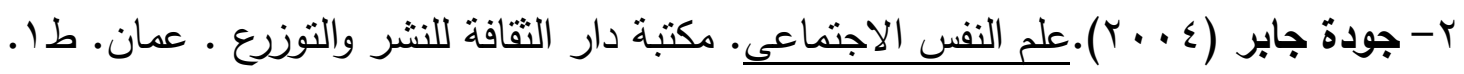

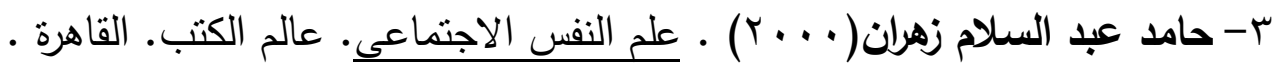

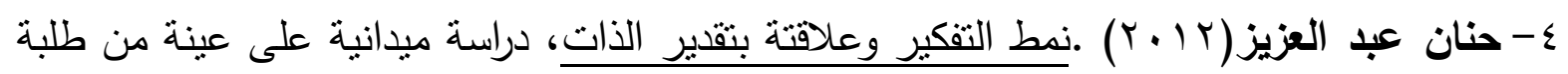

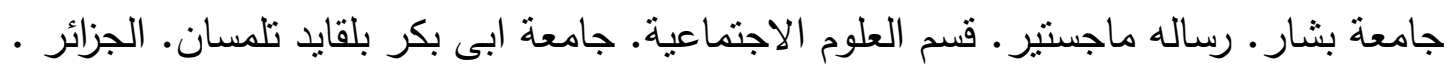

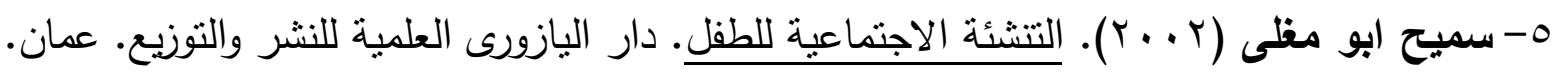
b 4-سهام ابراهيم كامل(1 . . ب). اتجاهات معلمات الاطفال نحو العمل مع الطفل في ضوء بعض

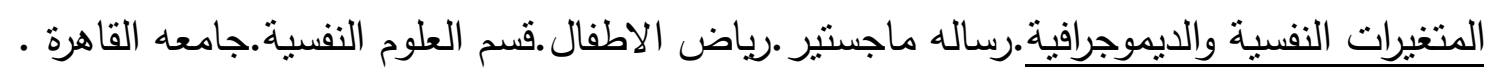

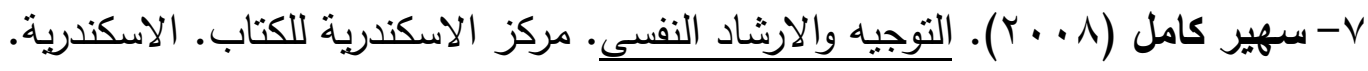

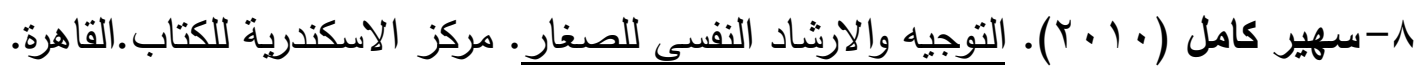

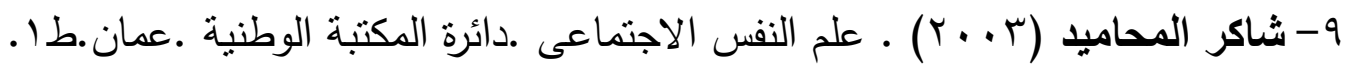

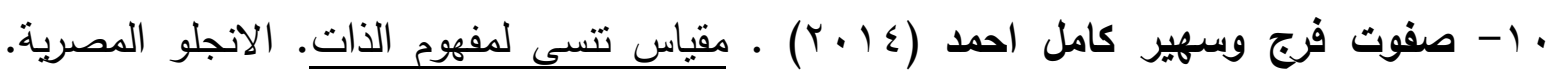

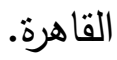

1ا- عمر نصر الله (r ..r). الاطفال ذوى الاحتباجات الخاصة وتاثيرهم على الاسرة والمجتمع.دار وائل للنشر والتوزيع .عمان.

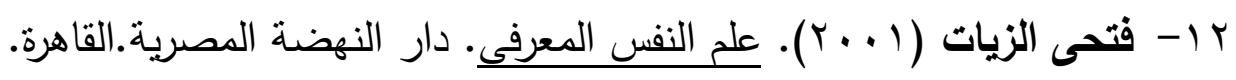

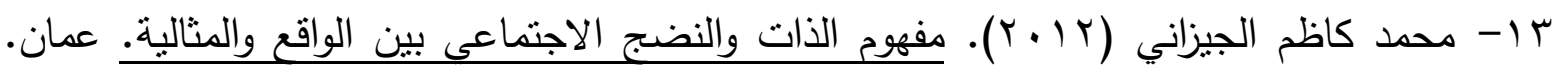
دار صفاء للنشر .

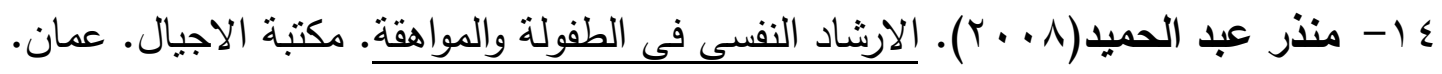


15- Bauman, N. \& Kuhl, J.(2002). Intuition affect and personality; unconscious Coherence judgment and self Regulation of negative affect. Journal of personality and social psychology, Vol,83, n. 5,pp1213-1220.

16- Bent,N.(2006). Beyond vividness;parental filters as moderates in mental imagery and measured anxiety level.Unpublished Doctoral Dissertation, Johan's university,New York.

17- Buss, A.(2001). Psychology Dimensions of the self.Sage publication, London.

18- Franzoi, S.(2003). Social psychology. Gern Hill; publisher, New Jersey.

19- Hippel, W. \& Hmkins, H.(2001). Stereotype distinctiveness; How counters stereotypic behavior shapes the self concept. Journal of personality and social psychology, Vol,81,n,2,p1213.

20- Mohamed Ebrahimi, Eissa Mohammadi, Hamzeh Mohmoudi and Ismail Ansari (2015). Stigma in mother of Deaf children. Iranian Journal of Otorhinolary ngology. Mar,27(79):109-118

21- Smith, M. \& Fong, R. (2004).The children of neglect.Burnner Routldge Co, New Yourk.

22- Wall, K.(2003). Special needs and early years. Paul Chapman publishing, New York. 